\section{International Scientific Journal Theoretical \& Applied Science}

\author{
p-ISSN: 2308-4944 (print) e-ISSN: 2409-0085 (online) \\ Year: $2015 \quad$ Issue: $10 \quad$ Volume: 30
}

Published: $30.10 .2015 \quad$ http://T-Science.org
Inna Aleksandrovna Serebryanik

Candidate of Technical Sciences, associate professor of the Department of World economy, Irkutsk National Research Technical University, Russia nasamolet@yandex.ru

\section{Alena Viktorovna Druzhinina}

Student,

Irkutsk National Research Technical University, Russia

SECTION 12. Geology. Anthropology. Archaeology.

\title{
SIBERIAN MICA CRAFT: FEATURES OF DEVELOPMENT
}

Abstract: The article investigates the development of the mica craft in the region Siberia (Irkutsk region, Krasnoyarsk territory and Yakutia). Shown the characteristic of micas deposits.

Key words: mica, Siberia, field, production of mica.

Language: Russian

Citation: Serebryanik IA, Druzhinina AV (2015) SIBERIAN MICA CRAFT: FEATURES OF DEVELOPMENT. ISJ Theoretical \& Applied Science 10 (30): 35-39.

Soi: http://s-o-i.org/1.1/TAS-10-30-10 Doi: crossef http://dx.doi.org/10.15863/TAS.2015.10.30.10

\section{СИБИРСКИЙ СЛЮДЯНОЙ ПРОМЫСЕЛ: ОСОБЕННОСТИ РАЗВИТИЯ}

Аннотация: В статье исследованы вопросы развития слюдяного промысла в регионе Сибири (на примере иркутской области, Красноярского края, Якутии). Дана характеристика месторождений слюды.

Ключевые слова: слюда, Сибирь, месторождение, добыча слюды.

В истории горного дела России ни одна отрасль, пожалуй, не имеет таких глубоких народных корней, как слюдяной промысел. Он зародился на Русском Севере на рубеже X-XI вв. на северо-западном побережье Белого моря.

В XVII в. возникает сибирский центр добычи слюды. К середине XVII века Сибирь уже стала самостоятельным центром слюдодобычи. Конечно, карельский опыт использовался, однако развитие шло самостоятельно.

Петр I проявлял значительный интерес к развитию слюдяного промысла в Сибири. Царскими указами сибирским воеводам приписывалось «...приискивать и расспрашивать всяких чинов людей и иноземцев про золотую и серебренную, и про медную, и оловянную, и свинцовую руды, и про жемчуг, и слюду, и краски, и про железо и про иные узорочья» [7; С.68]. Так, в 1701 г. Петр велит: «Сыскать слюду, наломать ее, для образца прислать к Москве в Сибирский приказ, стараться продавать в Китай».

В Сибири, в частности на территории будущего Красноярского края, добыча слюды началась в XVII в. с рудокопок по рекам Тасеевой, Кану и Барге.

По реке Тасеевой (река на западе Восточной Сибири, правый приток Ангары) отдельные разработки, начатые в 1642 году, представляли собой ямы по две сажени в глубину и ширину. Добычу слюды вел энергичный предприниматель Алексей Жилин [8; С.123]. Слюда не была его единственным интересом, Жилин занимался также солеварным производством, поисками меди, золота.

В 1658 г. в Москве он добился грамоты на право вести промыслы без перекупа и об отводе земельных участков под них на условии десятинной пошлины с добытого, не требуя никакого пособия. Месторождение, которое он открыл, называется Кондаковским - по одноимённому названию ближайшей деревни. Это месторождение эксплуатировалось с перерывами до середины XX века. Кроме того, Жилин получил право заниматься своими разведками за пределами Енисейского уезда. При этом он обязывался представлять воеводам образцы приисканных руд, а воеводам приказано было незамедлительно направлять эти образцы в Москву в Сибирский приказ.

В то время слюда применялась главным образом вместо оконных стекол. В Енисейском районе до сих пор сохранилась церковь со вставленной в оконные рамы слюдой. До ХХ века сохранялась добыча слюды ручным бурением. Здесь залегали уникальные богатейшие пласты. 
Вырезали кристаллы два на два метра. Откатка породы велась тачками, а подъем - двухконным воротом.

В том же году заявку на слюду сделал боярский сын Андрей Бармышлев, «иноземец, Немчин... до крещения имя ему было Вилим Иванов». Это почти единственный случай, когда в XVII веке в Сибири проявил себя на исследовательском поприще иностранец. Бармышлев сообщил о нахождении двух слюдяных гор по речке Кие, в ста верстах ниже Енисейска. Слюда, образцы которой он доставил, была, по его утверждению, лучше той, которую нашел Жилин. Он объяснял ее качество тем, что она находится на высоком месте, не затопляемом вешней водою, и не имеет ржавчины.

Жилин вел разработку слюдяных залежей вблизи Усолья (приток реки Тасеевой), за год он добывал от 40 до 66 пудов. Однако, в 1666 г. енисейскому воеводе было дано поручение произвести тщательное обследование жилинских слюдяных приисков, т.к. в Москву поступала слюда плохо качества. Одновременно последовало строгое указание о необходимости борьбы с недозволенной продажей лучших сортов слюды в Сибири.

Вскоре Жилин прекратил слюдяной промысел. Следовательно, он занимался поисками ископаемых в Приенисейской тайге 16 лет.

Начало XX века было временем не только «золотой», но «слюдяной лихорадки». Зародившаяся и бурно развивавшаяся электротехническая промышленность требовала много слюды. Она использовалась при изготовлении широкого спектра изделий - от свечи зажигания до электрогенератора. Цены на слюду резко подскочили, на поиски дорогого минерала бросились многочисленные искатели. Предприниматели вкладывали деньги в разведку и добычу.

Имеются архивные материалы, свидетельствующие о многих изыскателях месторождений слюды в районе Барги того же времени вплоть до 1917 г.: Варпаховский, Чухлонцев, Иванов, Шнейдер, Шильников и другие[5; С.66].

Среди таких разведчиков слюды были и братья Косовановы - Виктор Петрович и Вячеслав Петрович, впоследствии ставшим первым профессором геологии в Красноярском крае. Первую заявку на освоение Баргинского месторождения Косовановы подали в 1903 году. Ими было изыскано 15 выходов слюдяных скоплений в пегматитах. Так началась первая в России промышленная добыча слюды. В 1915 году все отводы братьев Косовановых и соседние Шильникова приобрели акционеры общества «Сибирская слюда».
Будущий академик A.Е. Ферсман, побывавший на Баргинском месторождении, так описывает ситуацию на руднике в то время: «Разработка идёт под землёю горизонтальными ходами, прихотливо извивающимися, согласно простиранию жил, и довольно круто падающими на юг. Выламываемая слюда выносится на дневную поверхность, где после сушки поступает в особое помещение; здесь больше десятка девушек сортируют её, просматривая на свет её чистоту, расщепляют, оскабливают верхний слой, несколько разрушенный поверхностными водами, и ножом отрезают изломанные или загрязнённые края. Слюда затем сортируется по величине. Все остатки и вырезки от этой работы не пропадают; они вновь просматриваются мальчиками и девушками, часть их даёт после расщепления тонкие прозрачные листочки, другая - может служить материалом для приготовления различных слюдяных препаратов» [6; С.10].

Владельцы рудника, хорошо оборудовав его, постоянно наращивали объёмы добычи. На шахтах было задействовано 47 отводов на площади 200 десятин. На многих отводах залегала калийная слюда-мусковит отличного качества, она оценивалась в 5000 пудов.

В 1917 году предприятие было национализировано, и дальнейшие разработки продолжались уже Советом народного хозяйства.

В 1650 г. казак Сидор Васильев объявил о находке слюды на р. Витим. Витимская слюда была найдена не сразу. В якутском архиве имеется доклад, посланный одним из тамошних воевод Трауернихту, затем знаменитому Андрею Виниусу в Сибирский приказ в конце прошлого столетия, где сообщается о слюдяных рудниках на реках Алдане и Чаре во владениях якутского жителя казака Ивана Лыткина, но ни слова о Витиме не упоминается.

Еще в 1680 году было известно о нахождении слюды у ручья Элдмак, впадающего в Тонтору, и несколько лет спустя у ручья Мамушкана, а в 1688 году у реки Зеи.

По архивным документам в августе 1689 г. Якутский воевода Петр Зиновьев выдал служилому казаку Афанасию Пущину «Наказную память», в которой тот обязывался «...сыскать и промыслить по Витиму-реке слуды доброй и какова получица». Этот год и берется за точку отсчета истории мамского промысла» [6; С.10].

Документально установлено, что первооткрывателем мамской слюды казак Якутского воеводства Петр Дураков. В 1689 году он доставил в воеводскую избу отличные образцы широколистной прозрачной слюды [6; C.11].

Хотя поиски слюды по Витиму производились, согласно архивным данным, 
приблизительно с 1689 г, серьезные исследования начались лишь с 1705 г., когда была сделана первая заявка на крупнокристаллическую слюду по р. Витиму. В 1704 г. илимский воевода Федор Родионович Каршанов был в Киренском остроге, где несколько вкладчиков тамошнего монастыря 26-го мая внесли челобитную и просили его разрешения добывать на Витиме и впадающих в него ручьях слюду, так как они получили известие, что там таковая имеется; они обязались десятую часть всего, чего найдут, внести в казну. У илимского воеводы в старых архивах имелись приказы о посылке казаков на поиски слюды, поэтому он без колебаний дал разрешение. Согласно этому разрешению, компания 1-го июня того года отправилась на Витим и вернулась с хорошей добычей осенью. Ее следует считать первой, открывшей на Витиме слюду. Существовало несколько рудников: у ручья Коссова, который примерно в 10 верстах выше устья Нижней Мамы впадает в означенную Маму c южной стороны, получивший от своего открывателя название Скорнянского; на речке Луговке, впадающей 12 верст повыше с той же стороны в Маму, названный Луговским; у речки Слюдянки, впадающей в 8 верстах выше в Луговку с севера; у речки без названия, которая в впадает с востока в Красную (оная впадает в полдня пути или в 12 верстах с севера в Маму); у речки Барчихи, впадающей в 30 верстах ниже Нижней Мамы в Витим, в 30 или 40 верстах выше его устья на южном берегу, вблизи лежащего на юге гольце Челым-чале, или Челинченды, видного с Витима, не говоря о множестве других.

Витимская слюда была признана лучше любой другой. Лучшей считали слюду светлую, а та, что с зеленым оттенком считается намного хуже. Следом оценивался размер слюды.

В 1707 г. добыча мамской листовой слюды уже составляла 1270 пудов (20 т), что составляло 200 т в переводе на забойный сырец [6; С.11]. С этого времени на другие места перестали обращать внимание, и вскоре они пришли в полный упадок. Слюдяные копи в бассейнах реки Витима, Мамы и Чуи крепли и развивались.

В связи с истощением беломорский слюдяных полей Петром I в 1719 г. был издан Указ с объявлением горной свободы, который значительно повысил инициативу поисковиков в открытии сибирских месторождений слюды.

При Екатерине II в 1771 г. был издан Указ, возлагавший на Главное управление Сибирских заводов расширение казенного слюдяного промысла на Маме. Слюдяной промысел для жителей Ленских поселений стал фамильным делом, опыт поисков и добычи слюды передавался от отца к сыну. Слюдодобытчики объединялись в артели численностью от 5 до 40 человек, а артели в общину (100 - 150 артельщиков), которые по рекам Лене и Витиму подымались до впадения последней в реку Мама, стараясь достигнуть ее к Петру и Павлу (церковный праздник в середине июля). Местом начального сбора артельщиков была маленькая слобода, стоявшая против устья р. Витим (ныне поселок с одноименным названием).

В XVIII веке на ежегодных иркутских ярмарках слюда занимала видное место во всем обороте торговли. Здесь российские купцы закупали крупными партиями мамскую слюду и вместе с традиционными сибирскими товарами - пушниной, кожей, серебром - вывозили ее в Европейскую Россию на Ирбитскую ярмарку и в Москву.

К листовой слюде, отправляемой в казну и на ярмарки, относились очень бережно. Для служилых, сопровождавший слюдяной груз, была разработана специальная инструкция, которая неукоснительно соблюдалась.

К середине XVIII века промысел слюды в Мамской тайге был крупным и хорошо организованным горным производством. Однако по мере роста выпуска листового стекла спрос на мусковит начал падать. С середины XIX в. Угасающий слюдяной промысел захватили Витимские купцы. К 1890 г. добыча слюды в районе прекратилась повсеместно. Интерес к мамской слюде вернется лишь в начале XX века, когда слюда станет интересной для нужд электротехнической промышленности.

Главной же слюдяной базой России была Иркутская губерния. В 1682 г Селенгинский воевода Иван Астафьевич Власов пишет царю Федору Алексеевичу о поисках в округе Байкала руд и слюды. ...посылал я холоп твой во все остроги к прикащиком и к ясашным сборщиком к служилым людем памяти, чтоб они у ясачного соболиного сбору у иноземцев у ясачных людей про золотую руду, и про серебро, и жемчюг, и каменье, и медь, и олово, и свинец, и железо проведывали и спрашивали со великим домогательством. И в нынешнем, Государь, году писал ко мне из Ангарского пятидесятник казачей Трошка Щербаков, а в отписке его написано: у ясачного де соболиного сбору сказал ему тунгус, именем Дзидзягда: есть де у Байкала озера, в урочище за Котюшною рекою, в горе, слюда, и он де Трошка с тем тунгусом посылал из Ангарского служилых людей Андрюшку Маркова с товарищи к тому месту той слюды проведывать; и Андрюшка де с товарищи к тому месту с тем тунгусом ходили, и взломали той слюды полпуда, и он Трошка ту слюду с ним Андрюшкою прислал ко мне холопу твоему... А я холоп твой руды и того камени уломок, в котором каменю та руда отыскана, и слюду, какова сыскана, послал к тебе Великому Государю к 
Москве со служилыми людми, которые посланы за твоею Великого Государя баргузинскою и иркуцкою соболиною казною...

Вообще И. Власов явился талантливым организатором горного дела на большой территории. Исполнителями же горных поисков стали служивые люди Иркутского и Тункинского острогов.

В 1684 г. Иркутский письменный голова Леонтий Кислянский доносил енисейскому воеводе князю Константину Щербатову, что по «распросным речам» обротчика Пашки Микитина Панушко у истоков Ангары реки «есть слюда в каменю, на берегу Байкала озера, а от усть Ангары реки только де версты с три, и чают де в том месте по признакам слюды добрые...» [11; C.5].

В другой отписке Леонтия Кислянского в Енисейский острог, отправленной после 25 мая 1684 г., говорится, что, по словам иркутского казака Мишки Епифанова «есть де подле Байкала озеро, по ею сторону, между реками Большою и Малою Бугылдейками, слюда, а неподалеку от того места кочюют Верхоленского острогу ясашные брацкие люди, и те де ясачные Верхоленского острогу братцкие люди ту слюду видают беспрестанно...» [11; С.6]. Однако, верхоленские буряты не указали точного расположения месторождений слюды, так как у М. Епифанова не было подарков для них.

Придавая, очевидно, большое значение добыче слюды, иркутский воевода Леонтий Кислянский распорядился отправить с пятидесятником казачьим Онисимом Михалевым, с посадским человеком С. Семеновым и с М. Епифановым подарки для бурят - сукна, олово и мишуру, чтобы выведать, где находится месторождение слюды. Тому, кто укажет место, где имеется слюда, было обещано освобождение от ясачного платежа «навечно». Однако найти пригодные для добычи месторождения слюды не удалось.

В расспросе Онисим Михалев показал, что у p. Большой Бугылдейки слюды «сыскать де не могли: а признак де слюдных есть много, лежат по горам и по буграм лоскутки слюдные в полефимка и меньше и на степях де по многим же местом лежит мелкая слюда, что блески светят, а пожилицы де они не сыскали...». Оттуда же, с р. Большой Бугылдейки, Онисим Михалев привез в Иркутск образцы пород - «в одном ящике руда, называют, ее по немецки оловко, а по руски карандаш самой прямой»,- которой, по словам О. Михалева, «в горе есть де его много».

Осенью 1902 г. Якуниным было открыто месторождение на левом склоне Слюдянки. В 1903 г. он открыл и застолбил площади, на которых в 1912 г. были отведены слюдяные рудники «Никольский» и «Макарьевский». В
1910 г. он открыл слюду на горе. В 1916 г. один из «рудознатцев» Георгий Андреевский (житель Слюдянки), сообщал, что им обнаружено месторождение слюды в двух верстах от железнодорожного вокзала. Это был склон горы между устьем реки Похабихи и устьем Слюдянки. В последствие Андреевский займется поставками слюды для нужд оборонной промышленности, став владельцем Макарьевского и Никольского слюдяных рудников, расположенных вблизи ст. Слюдянка Забайкальской железной дороги.

После революции 1917 г. разработка полезных ископаемых будет на какое-то время остановлена. Промышленная добыча слюды началась в Слюдянском районе в 1924 г. Институтом прикладной минералогии, управлением Забайкальской железной дороги и Госторгом. В 1927 г. будет образован Сибслюдтрест, в ведение которого войдут все слюдяные месторождения Иркутской области.

Освоение и изучение Сибири приводит к новым открытиям. В 1683 г. «Камчатский Ермак» Владимир Атласов сообщит о наличии слюды на Алдане. В феврале 1683 г. Владимир был лично допрошен якутским воеводой И. В. Приклонским.

Одновременно Атласов доложил воеводе о некоторых нарушениях порядка сбора ясака на реке Учур. В частности, по поручению учурского приказного казачьего пятидесятника Ивана Жиркова, он «известил» воеводу о том, что учурские эвенки жалуются на различные злоупотребления сборщика ясака Ивана Усакина. Усакина вызвали для ответа в приказную избу Якутска и там ему простили все его прегрешения за то, что он поведал об удивительном: на реках Тонтора и Гонам (приток Учура) Усакин обнаружил богатые залежи слюды и два пуда «для опыту» доставил в Якутск [4; С.35].

Возникли слюдяные ломки на реках Алдан, Чара, Томтора, Зея. Первыми разработчиками слюды стали якутские казаки И. Лыткин и Т. Творогов.

Месторождения эти позднее были забыты, и только через 250 лет, перед самой Великой Отечественной войной были открыты вновь. Тогда же началась их эксплуатация, дававшая слюду для обороны страны.

Добыча слюды в Сибири продолжалась, видимо, дольше, чем в Карелии [8; С.124]. "Ломка слюды, проводящаяся на Алдане с 1689, а на Маме с 1705 года, составляет по сей стране главный промысел многих поселян. Они соединяются артелями человек по сорок, кои выбирают себе старосту, который распоряжает у них дела и ведет щеты. Ломщики закупают из общей складки утварь, съестной запас и пр. Добытую слюду за один поход продают сообща, и делят между собой деньги по мере участия 
каждого. Обыкновенно двое из них исправляют кузнечную работу, двое кашевары, а двое приискивают и обнаруживают новые слюдяные места... " [8; С.178].

Ломщики или как их еще называли слюдяники разделяют добытую слюду на три разбора: мелкую (шитуха), ее листы имеют не более 4 дюймов в квадрате $\left(25 \mathrm{~cm}^{2}\right)$; среднюю от 5 до 10 квадратных дюймов (от 30 до $65 \mathrm{~cm}^{2}$ ); широколистную в один фут $\left(930 \mathrm{~cm}^{2}\right)$ и более. Такую слюду не расщепляли.

Если говорить об использовании слюды, то она уже в гораздо меньших объемах употреблялась для окон, в это время уже появилось стекольное производство. Однако значительное количество слюды использовалось для корабельных окон, фонарей, окон малых домов в деревнях Сибири. Слюдяные окна зимой не обмерзали, чистились мыльной водой.

В начале прошлого столетия в Сибири было известно три крупных месторождения слюды:
Мамское - в Якутии, Слюдянское - в Забайкалье и Канское (Канско-Баргинское) - при впадении речки Барги в Кан. XVI - XVIII века - золотое время в истории слюдяного промысла Сибири. Сибирская слюда считалась бесценным стратегическим сырьем.

Слюдяной промысел в России развивался до середины XVIII в., затем, в связи с широким распространением стекла, стал приходить в упадок, а в таких крупных районах, как Мамско-Чуйский, к концу XIX в. совершенно прекратился. Россия, обладавшая месторождениями слюды мировой значимости, в начале XX века почти полностью прекратила добычу слюды, а небольшое количество ее ввозилось из-за границы. Новый подъем слюдяной промышленности относится к периоду развития электропромышленности, когда слюду стали использовать в качестве изоляционного материала.

\section{References:}

1. Arhiv gazety Vlast' truda: [sajt]. Available: http://ellib.library.isu.ru/vlast_truda/index.p hp (Accessed: 03.10.2015).

2. Dubenskij AM, Leonov CB, Bajnblat JS (1985) Obogashhenie listovyh sljud, Irkutsk: Izd-vo Irkut.un-ta, 1985. - 184 p.

3. Dubovik MM, Libman JP (1966) Dve zhizni chudesnogo kamnja: Iz istorii sljudjanogo promysla v Rossii. - Moscow: Nedra, 1966. - $188 \mathrm{p}$.

4. Dulov AV (1990) Pamjatniki istorii i kul'tury Priangar'ja. - Bimkom, 1990. - 288 p.

5. Volobuev GT (2009) Centr sljudjanogo proizvodstva v Krasnojarskom krae // Sibirskij subjetnos: kul'tura, tra-dicii, mental'nost': materialy V Vserossijskoj nauchno-prakticheskoj Internet-konferencii na sajte sib-subethnos.narod.ru, 15 janvarja - 15 may 2009 goda / Federal. agentstvo po obrazovaniju, GOU VPO "Krasnojar. gos. ped. un-t im. V. P. Astaf'eva". - Krasnojarsk : KGPU im. V. P. As-taf'eva, 2009. pp. 6578 .
6. (2000) Gody i ljudi sljudjanoj Mamy: (Istorija Mamsko-Chujskoj jekspedicii) / M. I. Verhoturov [i dr.]; Irkut. gos. tehn. un-t . Irkutsk: Izd-vo IrGTU, 2000. -324 p.

7. Nikitin AN (1990) Osvoenie Sibiri v XVII v. /A.N. Nikitin.- Moscow: Pro-sveshhenie, 1990. -143 p.

8. Petrov VP (1978) Rasskazy o treh neobychnyh mineralah / V. P. Petrov. - M.: Nedra, 1978. - 177 p.

9. Polevoj BP (1997) Novoe ob otkrytii Kamchatki : v 2 ch. / B. P. Polevoj. Petropavlovsk-Kamchatskij : izd-vo "Kamch. pech. dvor", 1997. Ch. 1. 160 p. Ch. 2. 204 p.

10. Prjanishev BG (2001) Irkutskaja sljudjanaja fabrika v 1930-h gg. //Vestnik Tomskogo gosudarstvennogo universiteta - №2(14) 2001. pp.124-126.

11. Rumjancev LI (1958) Russkie istoch-niki XVII v. o Bajkale // Kraevedche-skij sbornik. / Pod red. L.E. Jeliasova. - 1958. Vyp. 3. pp.3 - 12. 